\title{
MUSCLE DISORDERS IN ADOLESCENT IDIOPATHIC SCOLIOSIS: LITERATURE REVIEW
}

\author{
DISTÚRBIOS MUSCULARES NA ESCOLIOSE IDIOPÁTICA DO ADOLESCENTE: \\ REVISÃO DA LITERATURA
}

\author{
ANORMALIDADES MUSCULARES EN LA ESCOLIOSIS IDIOPÁTICA \\ DEL ADOLESCENTE: REVISIÓN DE LA LITERATURA
}

Débora Pinheiro Lédio Alves', Barbara de Araújo ${ }^{1}$

1. Irmandade da Santa Casa de Misericórdia de São Paulo, Musculoskeletal Physiotherapy Course of Study. Department of Specialization in Musculoskeletal Physiotherapy, São Paulo, SP, Brazil.

\begin{abstract}
Scoliosis is characterized by three-dimensional changes of the spine and is estimated to be present in $4 \%$ of the population worldwide. The most common form is the adolescent idiopathic. The purpose of this study is to identify the major muscle abnormalities found in patients with adolescent idiopathic scoliosis through a literature review. We conducted an electronic search of the national databases PubMed, Lilacs, PEDro, and EMBASE using the keywords "scoliosis", "biomechanics", "exercise", "physical therapy specialty", "idiopathic", and "muscles", from January 2003 to April 2015. The most relevant articles in English, Portuguese and Spanish were selected by title and abstract. It was also performed a manual search of the references of the selected articles. From a total of 4,319 articles, 11 were selected. We conclude that individuals with AIS have changes in the paraspinal muscles, with a difference in activation between the concave and convex sides, suggesting an increase in EMG activity on the convex side, although there is still no consensus among the authors.
\end{abstract}

Keywords: Scoliosis, Biomechanical phenomena; Adolescent; Exercise, Physical therapy specialty; Muscles.

\section{RESUMO}

A escoliose é caracterizada por alterações tridimensionais da coluna vertebral e estima-se estar presente em torno de 4\% da população mundial. A forma mais comum é a idiopática do adolescente. O objetivo deste estudo é identificar as principais alterações musculares encontradas nos pacientes com escoliose idiopática do adolescente por meio de uma revisão da literatura. Foi realizada a busca eletrônica nas bases de dados nacionais PubMed, Lilacs, PEDro e EMBASE usando as palavras-chave "escoliose", "biomecânica", "exercício", "fisioterapia", "idiopática" e "músculo", de janeiro de 2003 a abril de 2015. Os artigos mais relevantes em português, inglês e espanhol foram selecionados pelo título e pelo resumo. Também foi realizada busca manual nas referências dos artigos selecionados. Do total de 4.319 artigos, 11 foram selecionados. Concluímos que os indivíduos com EIA têm alterações nos músculos paravertebrais, com diferença de ativação entre os lados, côncavo e convexo, o que sugere um aumento na atividade EMG no lado convexo, embora ainda não haja consenso entre os autores.

Descritores: Escoliose; Fenômenos biomecânicos; Adolescente; Exercícios; Fisioterapia; Músculos.

\section{RESUMEN}

La escoliosis se caracteriza por cambios tridimensionales de la columna vertebral y se estima que esté presente en el 4\% de la población mundial. La forma más común es la idiopática del adolescente. El objetivo de este estudio es identificar las principales anomalías musculares que se encuentran en los pacientes con escoliosis idiopática del adolescente a través de una revisión de la literatura. Se realizó una búsqueda electrónica de las bases de datos nacionales PubMed, Lilacs, PEDro y EMBASE utilizando los descriptores "escoliosis", "biomecánica", "ejercicios", "fisioterapia", "idiopática" y "músculo" desde enero 2003 a abril de 2015. Fueron seleccionados los artículos más relevantes en portugués, inglés y español por el título y el resumen. También se realizó una búsqueda manual de las referencias de los artículos seleccionados. Del total de 4.319 artículos, se seleccionaron 11. Llegamos a la conclusión que los individuos con ElA presentan cambios en los músculos paravertebrales, con una diferencia de activación entre los lados cóncavo y convexo, lo que sugiere un aumento de la actividad EMG en el lado convexo, aunque todavía no exista consenso entre los autores.

Descriptores: Escoliosis; Fenómenos biomecánicos; Adolescente; Ejercicio; Fisioterapia; Músculos.

\section{INTRODUCTION}

Scoliosis is a word of Greek origin used to classify changes in the spine, thorax, and trunk, characterized by three-dimensional changes, with lateral deviation in the frontal plane, rotation in the transverse plane, and reduced curvature in the sagittal plane. It is present in approximately $4 \%$ of the world population and $70-80 \%$ of cases are idiopathic in origin, that is, without any specific etiology. ${ }^{1-20}$
Among the types of idiopathic scoliosis, the most common is that of the adolescent (AIS), which affects individuals during the growth period from 10 to 18 years of age, ${ }^{1-10}$ being more common in females. With no definite etiology, various studies have suggested that it is multifactorial, with hypotheses that range from genetic and hormonal influences, changes in the nervous system, and deficient postural control to changes in the cartilaginous tissue and intervertebral discs, abnormalities in the growth of bones

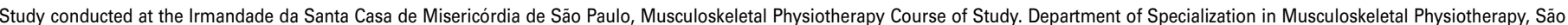
Paulo, SP, Brazil.

Correspondence: Rua Domingos Delgado, 138, Vila Souza, São Paulo, SP, Brasil. 02881-070. barbara_de_araujo@ @otmail.com 
and the spine, biomechanical and activity changes, and changes in the length of the paraspinal musculature. , $, 8,20-22^{-}$

The treatment of AIS depends on the magnitude of the curve, which is classified according to the angulation. Values between $10^{\circ}$ and $20^{\circ} / 25^{\circ}$ are considered mild and the indicated treatment is physical therapy or observation. Curves between $20^{\circ}$ and $40^{\circ} / 45^{\circ}$ require the use of braces and physiotherapeutic treatment. Finally, values above $40^{\circ} / 45^{\circ}$ are indicated for surgical treatment. ${ }^{6}$

Specific exercises are widely used in Europe for the treatment of AIS and are promoted by various schools, unlike in the American countries where this practice is not so widespread. ${ }^{23-25}$

The treatment of AIS is basically divided into conservative and surgical approaches, with weak evidence for conservative treatment with conventional physiotherapy and stronger evidence for the use of braces or surgery when indicated. ${ }^{1,6,8,9,15,23,25}$

Among the factors suggested as causes of the disease, the muscular factor is a subject of intense research as both a cause and a consequence of the deformity, but there is still no consensus as to whether the paravertebral musculature directly influences the beginning and the progression of scoliosis or whether the changes found in the fibers, strength, and electromicrographic activity are characteristics secondary to the deformity. ${ }^{2,22,23}$

AIS, in addition to being characterized by three-dimensional changes in the spine, presents changes in the positioning and biomechanics of other segments, visible in the physical exam, such as change in the positioning of the shoulders, shoulder blades, and pelvis, which are related to the progression of the curve and may suggest that the musculature involved in the work of these structures is compromised, whether from compensation for the changes imposed by the deformity or as a result of the structural changes themselves..$^{1-10,19}$

The number of structural changes found in these patients makes us think about their influence on normal biomechanics and about the consequences for muscle function.

It is not known for certain to what point the scapular and lower limb muscles suffer as a consequence of the structural changes imposed by AIS or how the paraspinal musculature participates in the development and progression of the curve. We only know that the changes are there and that it is hard to say how and why they manifest themselves.

The objective of this study was to identify the principal muscular changes found in patients with adolescent idiopathic scoliosis through a review of the literature.

\section{METHODS}

We performed an electronic search of the PubMed (Public Medline), LILACS (Literatura Latino-Americana e do Caribe em Ciências da Saúde [Latin American and Caribbean Health Sciences Literature]), PEDro (Physical therapy Evidence Database), and EMBASE (Biomedical Data Base) data bases using the keywords "scoliosis", "biomechanics", "exercises", "physical therapy", "idiopathic", and "muscle", previously consulted in DeCS (Descritores em Ciências da Saúde [Health Sciences Key words]) and MeSH (Medical Subject Headings). The keywords were combined using the Boolean operator "and" a search of works from the period of January 2003 to April 2015 was performed to identify clinical trials and prospective crosssectional and cohort studies about the proposed subject.

The most relevant articles on the theme were selected by the investigator based on title and abstracts and the Oxford table was applied, which classifies the works on a scale of 1 to 5 , where the lower the score, the better the level of evidence.

Following selection of the articles by electronic search, a manual search of the references of the chosen articles was conducted to avoid losing any articles that were relevant to the study.

The inclusion criteria adopted were language (English, Portuguese, and Spanish), target population (adolescent), etiology (scoliosis of idiopathic origin), type of study (except case studies), species (human), and archives from the period between January 2003 and April 2015.
Studies that involved surgical treatment, the administration of medications, studies of cadavers, comparative studies or orthoses, software analyses, studies that did not discuss the muscular changes found in adolescent idiopathic scoliosis, articles about respiratory changes, sensory motor response, changes during walking, and the application of specific treatment protocols were excluded.

\section{RESULTS}

With the combination of the words 'scoliosis' and 'biomechanics', 302 articles were found: two in LILACS, 157 in PubMed, and 143 in EMBASE in five journals and none in the PEDro data base. Only two articles, from the PubMed database, were selected.

By combining the words 'idiopathic', 'scoliosis', and 'exercises', 25 articles were found: 240 in PubMed, three in LILACS, and 13 in PEDro. EMBASE did not return any articles in the search, but only books. Four articles were selected from the PubMed data base.

The search using the keywords 'scoliosis' and 'physical therapy' returned 1056 articles:, seven from PEDro, 946 from PubMed, 71 articles from three EMBASE periodicals, and 30 from LILACS. Two of the PubMed and one of the LILACS articles were chosen.

The last search was performed combining the keywords 'scoliosis' and 'muscle' and returned 2707 works: 1104 from the LILACS data base, 28 from PEDro, and 1532 from PubMed. Once again, EMBASE returned only 13 books. Only two of the PubMed data base articles were selected (Table 1).

The final total of works selected was 11, as no relevant works were found by the manual search. (Table 2 and Figure 1)

\section{DISCUSSION}

In past decades, various studies have proposed that the paraspinal musculature plays an important role in the mechanisms of idiopathic scoliosis. ${ }^{27}$ To some authors, the onset of AIS is the result of direct participation of this musculature, while to others, the changes found are secondary to the structural changes that occur in the development of the disease.

In addition to the changes in the paraspinal musculature, theories about changes in the muscles related to other segments have also been proposed, particularly those that function in the pelvic and shoulder girdles. However, currently there are few findings about the consequences of AIS on these structures and the paraspinal musculature is the greatest focus of research given its direct involvement with the spine. ${ }^{27-29}$

Lin et al. ${ }^{29}$ investigated the activation of scapular muscles using surface electromyography. Evaluating the superior and inferior trapezius, the serratus, and the anterior deltoid muscles of 13 pa-

Table 1. Bibliographical references identified by key words and databases searched

\begin{tabular}{c|c|c}
\hline Keywords & Data base & References located \\
\hline \multirow{2}{*}{ Scoliosis and } & Pubmed & 157 \\
biomechanics & PEdro & 0 \\
& LILACS & 2 \\
& EMBASE & 143 \\
\hline \multirow{2}{*}{ Idiopathic and } & Pubmed & 240 \\
scoliosis and & PEdro & 13 \\
exercises & LILACS & 3 \\
& EMBASE & 0 \\
\hline \multirow{2}{*}{ Scoliosis and physical } & Pubmed & 946 \\
and therapy & PEdro & 7 \\
& LILACS & 30 \\
& EMBASE & 71 \\
\hline \multirow{2}{*}{ Scoliosis and muscle } & Pubmed & 1575 \\
& PEdro & 28 \\
& LILACS & 1104 \\
\hline Total & EMBASE & 0 \\
\hline
\end{tabular}


Table 2. Description of research articles selected

\begin{tabular}{|c|c|c|c|c|c|}
\hline $\begin{array}{c}\text { Autor e } \\
\text { ano }\end{array}$ & $\begin{array}{l}\text { Type of } \\
\text { study }\end{array}$ & Oxford & Objective & Sample & Conclusion \\
\hline $\begin{array}{l}\text { Pingot } \\
\text { et al. }{ }^{28} \\
2007 \\
\end{array}$ & Intervention & $2 \mathrm{C}$ & \begin{tabular}{|c|}
$\begin{array}{c}\text { To evaluate the torque of } \\
\text { the hip flexor and exten- } \\
\text { sor muscles in IS. }\end{array}$ \\
\end{tabular} & $\mathrm{N}: 123$ & $\begin{array}{l}\text { Change in } \\
\text { strength on } \\
\text { both sides. }\end{array}$ \\
\hline $\begin{array}{c}\text { Lin et al. } \\
2010 .\end{array}$ & $\begin{array}{c}\text { Cross- } \\
\text {-sectional } \\
\text { paired con- } \\
\text { trol study }\end{array}$ & $2 \mathrm{~B}$ & $\begin{array}{c}\text { To determine whether } \\
\text { subjects with IS have } \\
\text { dysfunction of the shoul- } \\
\text { der kinematics and, if so, } \\
\text { whether it is related to } \\
\text { muscular activation. }\end{array}$ & N: 26 & $\begin{array}{l}\text { Change in } \\
\text { the EMG in } \\
\text { patients with } \\
\text { upper thoracic } \\
\text { curve. }\end{array}$ \\
\hline $\begin{array}{l}\text { Mahau- } \\
\text { dens } \\
\text { et al. }{ }^{30} \\
2005\end{array}$ & $\begin{array}{c}\text { Simple stu- } \\
\text { dy paired } \\
\text { for age and } \\
\text { sex }\end{array}$ & $2 \mathrm{~B}$ & $\begin{array}{l}\text { To evaluate the impact of } \\
\text { pelvic change secondary } \\
\text { to AIS and the efficiency } \\
\text { of the locomotor mecha- } \\
\text { nism, both in a standing } \\
\text { position and walking. }\end{array}$ & $\mathrm{N}: 24$ & $\begin{array}{l}\text { Change in the } \\
\text { paraspinal, } \\
\text { abdominal, } \\
\text { and lumbar } \\
\text { quadratus } \\
\text { muscles. } \\
\end{array}$ \\
\hline $\begin{array}{l}\text { Gaudre- } \\
\text { ault } \\
\text { et al. }^{31} \\
2005\end{array}$ & $\begin{array}{l}\text { Pilot study } \\
\text { (controlled) }\end{array}$ & $2 \mathrm{~B}$ & $\begin{array}{l}\text { To evaluate the paraspi- } \\
\text { nal muscles of the sub- } \\
\text { jects with IS using EMG } \\
\text { and to compare the } \\
\text { difference in activation of } \\
\text { the two sides. }\end{array}$ & N: 16 & $\begin{array}{l}\text { Change in the } \\
\text { EMG on the } \\
\text { convex side of } \\
\text { the curve. }\end{array}$ \\
\hline $\begin{array}{l}\text { Cheung } \\
\text { et al. }{ }^{32} \\
2006 .\end{array}$ & $\begin{array}{c}\text { Longi- } \\
\text { tudinal } \\
\text { prospective } \\
\text { study }\end{array}$ & $3 C$ & \begin{tabular}{|c|} 
To evaluate the develo- \\
pment of the curve, the \\
relationship between the \\
variables and the EMG, \\
and this relationship \\
during progression.
\end{tabular} & N: 105 & $\begin{array}{l}\text { Increase in the } \\
\text { EMG of the } \\
\text { convex side } \\
\text { during the } \\
\text { period of curve } \\
\text { progression. }\end{array}$ \\
\hline $\begin{array}{l}\text { Cheung } \\
\text { et al. }{ }^{33} \\
2005\end{array}$ & $\begin{array}{l}\text { Cross- } \\
\text {-sectional } \\
\text { study }\end{array}$ & $3 B$ & \begin{tabular}{|c|} 
To examine the rela- \\
tionship between the \\
EMG activity of the \\
paraspinal muscles and \\
the progression of the \\
scoliotic curve. \\
\end{tabular} & $\mathrm{N}: 23$ & $\begin{array}{c}\text { Relationship } \\
\text { between the } \\
\text { EMG activity } \\
\text { and the pro- } \\
\text { gression of the } \\
\text { curve. } \\
\end{array}$ \\
\hline $\begin{array}{l}\text { Oliveira } \\
\text { et al. }^{34} \\
2011\end{array}$ & $\begin{array}{c}\text { Prospective } \\
\text { clinical } \\
\text { study }\end{array}$ & $3 B$ & \begin{tabular}{|c|} 
To record and process \\
the myoelectric amplitu- \\
de of the erector spinae \\
muscles in IS and to \\
compare it with healthy \\
individuals. \\
\end{tabular} & $\mathrm{N}: 30$ & $\begin{array}{l}\text { Without diffe- } \\
\text { rence in acti- } \\
\text { vation between } \\
\text { the sides of } \\
\text { the curve. }\end{array}$ \\
\hline $\begin{array}{l}\text { Tsai } \\
\text { et al. }^{35} \\
2010\end{array}$ & $\begin{array}{l}\text { Cross- } \\
\text {-sectional } \\
\text { study }\end{array}$ & $2 \mathrm{~B}$ & \begin{tabular}{|c|} 
To evaluate paraspinal \\
activation in healthy \\
individuals and those \\
with IS during extension \\
and flexion of the trunk in \\
terms of angulation and \\
speed.
\end{tabular} & N: 74 & $\begin{array}{c}\text { Increased } \\
\text { activation of } \\
\text { the convex } \\
\text { side in patients } \\
\text { with moderate } \\
\text { curves. }\end{array}$ \\
\hline $\begin{array}{l}\text { Schimid } \\
\text { et al. }^{36} \\
2010\end{array}$ & $\begin{array}{l}\text { Cross- } \\
\text {-sectional } \\
\text { study }\end{array}$ & $3 B$ & $\begin{array}{c}\text { To investigate if asymme- } \\
\text { trical resistance training } \\
\text { focused on the concave } \\
\text { side of the curve increa- } \\
\text { ses the EMG activity on } \\
\text { the concave side. }\end{array}$ & $\mathrm{N}: 16$ & $\begin{array}{c}\text { Both exercises } \\
\text { can produce } \\
\text { an increase in } \\
\text { the EMG on } \\
\text { the concave } \\
\text { side. } \\
\end{array}$ \\
\hline $\begin{array}{l}\text { Chwała } \\
\text { et al. }^{37} \\
2014\end{array}$ & $\begin{array}{l}\text { Cross- } \\
\text {-sectional } \\
\text { study }\end{array}$ & $3 B$ & $\mid \begin{array}{c}\text { To evaluate the impact of } \\
\text { symmetrical and asym- } \\
\text { metrical exercises on the } \\
\text { activity of the paraspinal } \\
\text { muscles in girls with AIS. }\end{array}$ & N: 82 & $\begin{array}{l}\text { Change in acti- } \\
\text { vation between } \\
\text { the sides that } \\
\text { depends on } \\
\text { the type of } \\
\text { curve and } \\
\text { exercise. }\end{array}$ \\
\hline $\begin{array}{l}\text { Bassani } \\
\text { et al. }{ }^{38} \\
2008\end{array}$ & $\begin{array}{l}\text { Cross- } \\
\text {-sectional } \\
\text { study }\end{array}$ & $2 \mathrm{~B}$ & $\begin{array}{c}\text { To evaluate the neuro- } \\
\text { muscular efficiency and } \\
\text { fatigued lumbar exten- } \\
\text { sors in subjects with and } \\
\text { without AIS using the } \\
\text { EMG. }\end{array}$ & N: 20 & $\begin{array}{l}\text { Less strength } \\
\text { and neuro- } \\
\text { muscular effi- } \\
\text { ciency, without } \\
\text { difference } \\
\text { in activation } \\
\text { between the } \\
\text { two sides. }\end{array}$ \\
\hline
\end{tabular}

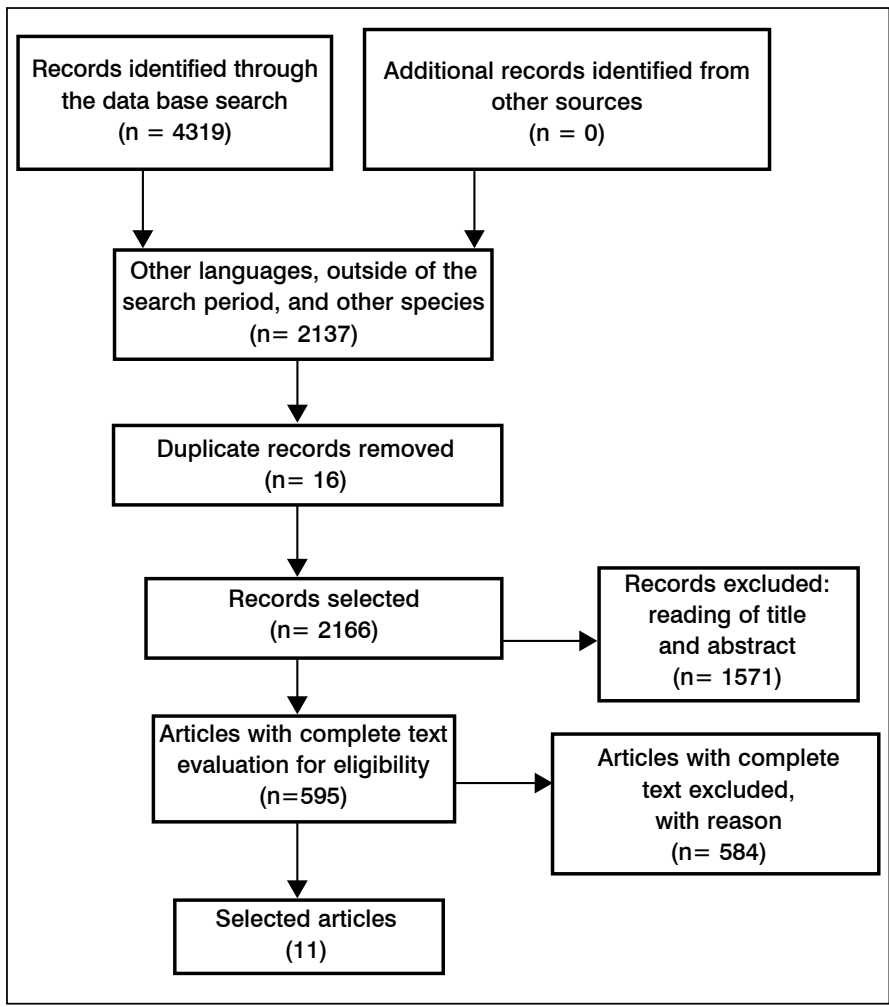

Figure 1. Study selection flowchart.

tients with AIS, they found a delay in the activation of these muscles both on the concave and convex sides when compared to healthy individuals. They also confirmed an increase in the activity of the serratus anterior and a decrease in the activity of the concave side of the inferior trapezius, findings that may be explained by the three-dimensional changes of scoliosis that alter the positioning of the shoulders and shoulder blades, as reported by Zabjek et al. ${ }^{19}$

Investigating the involvement of the hip musculature, Pingot et al. ${ }^{28}$ evaluated the strength of the flexor and extensor muscles in 123 patients diagnosed with AIS, all with mild curves. In their assessment, they discovered an increase in the strength of the flexors of the right hip and the extensors of the left hip in the group with lumbar curves to the left. In the group with lumbar curves to the right, they discovered greater strength in the left-side flexor and right-side extensor. Following six months of progressive load strength training, the results suggested that the strengthening of the hip musculature reduced the difference in strength between the lower limbs of the patients with AIS. ${ }^{27}$ The findings of Pingot et al. ${ }^{28}$ support the theory that the changes caused by AIS, especially those related to distortion and pelvic tilt, may result from a reduction in strength of the lower limb muscles, in this case the rectus femoris, iliopsoas, and gluteus maximus.

In 1983, Sahgal et al., ${ }^{27}$ in a morphological study that compared biopsies of the paraspinal and gluteus maximus muscles of 15 patients with the quadriceps muscles of eight healthy individuals, identified changes in the type of fiber in the individuals with AIS. Both the paraspinal and hip extensor muscles were affected in the individuals with AIS, suggesting at the time that the disease had a primarily muscular etiology. ${ }^{27}$ These findings may support the results reported by Pingot et al. ${ }^{28}$ since the change in the type of fibers predominant in the hip extensor musculature can result in weakness and differences in the strength of the limbs and the resistance between them.

Mahaudens et al ${ }^{30}$ evaluated and compared 24 individuals, divided into two equal groups of 12 with AIS and 12 in good health, for muscle strength (measured as proposed by Kendall) and activation while standing and walking using EMG to measure activity electromyographically. The quadratus lumborum, erector spinae, 
gluteus medius, gluteus maximus, and abdominal muscles were evaluated. In both groups, a decrease in the strength of the abdominal muscles was confirmed, but in the AIS group there was greater activation of the erector spinae and the quadratus lumborum muscles. No difference between the concave and convex sides of the curve were reported, but to the author, this change was a result of the compensatory mechanism that works to maintain the stability of the spine and pelvis in response to the structural changes suffered with scoliosis. ${ }^{31}$ Although these changes in the paraspinal musculature align with the findings of other authors, the doubt remains as to whether this mechanism is compensatory or primary in individuals with AIS.

To better understand the development and progression of scoliotic curves, Cheung et al., ${ }^{32}$ in a prospective longitudinal study, evaluated 105 patients with AIS over a period of three years, with a minimum follow-up of one year. The objective was to compare patients who had curve progression with those with no curve evolution and to confirm in what ways the paraspinal musculature could be influenced by this progression. Through digital reconstruction of spinal $x$-rays in AP and lateral view, they obtained the Cobb angle values for scoliosis, thoracic kyphosis, and lumbar lordosis. They also obtained EMGs of the surface of the paraspinal muscles in the apical and final vertebrae of the curves. The results suggested greater EMG activity on the convex side of the entire curve during the period of progression and an increase of muscular activity only in the apical vertebra once the period of progression had ended. ${ }^{32}$ These findings leave some doubt as to whether this increase in EMG activity comes from the progression of the curve or from the compensatory mechanism to prevent this progression. Moreover, the findings from this study suggest that axial rotation only occurs following the initial lateral deviation of the spine and that thoracic kyphosis seems to be related to the progression of the curve.

These findings agree with the study by Cheung et al., ${ }^{33}$ a pilot with 23 subjects in which, besides evaluating the EMG of the paraspinal muscles and the progression of the curve through digital reconstruction of radiographs, they evaluated the EMG of the latissimus dorsi muscle. The results were consistent with the previous study except that there was no evidence of changes in the activity of the latissimus dorsi muscles, only an increase in the EMG activity of the paraspinal muscles at the apex and end of the curve of the patients with progressive curves. ${ }^{32,33}$

Another controlled pilot study of 16 patients by Gaudreault et al. $^{31}$ in 2005 revealed EMG activity at four levels of the spine (the longissimus muscle at $\mathrm{T} 10$ and $\mathrm{L} 1$, the iliocostalis muscle at $\mathrm{T} 3$, and the multifidus lumborum at L5) and also the efficiency and fatigue levels at level $\mathrm{L} 3$ on the right. ${ }^{31}$ The six patients in the group with scoliosis had thoracic curves on the right, again suggesting a change in the paraspinal musculature of the convex side of the curve.

Also in an attempt to assess muscle activation at specific points of the spine, de Oliveira et al. ${ }^{34}$ evaluated the EMGs of the paraspinal muscles at levels T8, L2, and L5, in addition to the maximum voluntary isometric contraction of this musculature in 15 individuals with AIS and 15 healthy individuals. However, unlike what was described by Gaudrealt et al., ${ }^{31}$ there was no evidence of significant differences between the groups in the EMGs measured at different levels, except at L5, or in the Cobb angles of the samples (which may be explained by their use of a larger sample than Gaudrealt et al. ${ }^{31}$ ).

Tsai et al. ${ }^{35}$ evaluated the EMGs of the paraspinal muscles at levels T7 and L2 in 41 healthy individuals and compared them with 23 individuals with mild AIS $\left(10^{\circ}-20^{\circ}\right)$ and ten with moderate curves $\left(>20^{\circ}\right)$, as they performed isokinetic flexion and extension exercises of the trunk at $30 \%$ and at $90 \%$ and also divided the paraspinal musculature into medial and lateral regions. They found an increase in activity on the convex side except in the flexion at $30 \%$ s. The results of the groups with healthy individuals and those with mild curves were equal, while the group of subjects with moderate curves had an increase in EMG activity. This study showed the differences in muscular activity depending upon the magnitude of the curve. In spite of the small sample, it reinforced the hypothesis that the greater the angulation, the greater not only the biomechanical structural changes encountered, but also the greater the changes in muscular activity. ${ }^{35}$

In 2010, Schimid et al. ${ }^{36}$ compared the differences in the muscular activation on both sides of the curve in a single evaluation of 16 patients with IS while they performed four symmetrical and asymmetrical trunk extensor strengthening exercises, commonly used in the rehabilitation of patients with AIS. Of the 16 patients, nine had thoracic curves, three had lumbar curves, two had thoracolumbar curves, and two had double curves. Comparing the types of curves, they found no preferential activation of either the concave or the convex side associated with the predominant type. However, some of the exercises, symmetrical and asymmetrical, were capable of promoting greater activation of the musculature on the concave side, which could be beneficial if applied to these patients, as in some studies these muscles were shown to have reduced EMG activity. ${ }^{36}$

However, the 2014 study by Chwala et al. ${ }^{37}$ does not support this conclusion. After evaluating 82 girls with AIS divided into two groups, those with simple curves and those with double curves, both at rest and while performing symmetrical and asymmetrical exercises of the paraspinal muscles, the authors concluded that there is greater electrical activation of the muscles on the convex side in the individuals with simple curves during symmetrical and asymmetrical exercises that recruit the muscles of the side of the concavity of the curve, while in individuals with double curves, the pattern is reversed. The divergences between the two studies may be explained by the differences in the samples, the ages of the subjects, the positioning of the electrodes, and the exercises applied during the evaluation.

Both findings, if applied to the treatment of AIS, can favor the recovery of paraspinal muscle balance. However, there is a lack of controlled studies that compare exercises to determine which ones are truly beneficial.

Although most studies, and the structural change itself, suggest a change in muscular activation between the concave and convex sides of the scoliotic curve, the 2008 study conducted by Bassani et al. ${ }^{38}$ did not report results that corroborate this theory and these findings. They evaluated 20 patients, 10 with idiopathic scoliosis and 10 in good health, in whom fatigue was induced in the trunk extensor muscles by performing maximum voluntary isometric contractions. They assessed the responses with EMGs of levels L1 and L5 and concluded that, although the neuromuscular efficiency and strength of the group with scoliosis was significantly lower (42.6\%) when compared with the control group, there was no difference in activation between the concave and convex musculature of the individuals with scoliosis. Nevertheless, besides this being a small sample, there was a wide range in ages of the participating individuals ( \pm 13 years), the oldest of whom was 35 years of age. This is important because, at that age, the degenerative process may have already begun and the musculature may have been undergoing the process of liposubstitution. Another point to highlight is that it is not possible to classify all patients as suffering from adolescent idiopathic scoliosis unless they were diagnosed during adolescence, a point that was not cited in the study. Additionally, in AIS, the peak of curve progression occurs during peak growth. In a study with individuals outside of this age group, important changes present during the period of greatest change may be missed, a fact documented by Cheung et al. ${ }^{32,33}$

In general, all the studies agree that there are changes in the paraspinal musculature and they concur with recent findings around the scapular and hip flexor and extensor musculatures. While they report discrepancies in muscular activation and strength, there is still no study enabling us to determine whether musculature plays a direct role in the development of AIS or in the progression of the curve, or whether its activity is increased in trying to counteract this progression, or whether it acts differently in all evolutionary phases of scoliosis. 


\section{FINAL CONSIDERATIONS}

Individuals with AIS have changes in the paraspinal musculature, with differences in the activation between the concave and convex sides, suggesting an increase in the electromyographical activity on the convex side, even though there is no consensus among the authors about the reason for these changes or whether there are great differences between the sides. There is also the suggestion of changes secondary to the scoliosis process in the scapular and lower limb musculatures, especially the hip flexor and extensor muscles.

All authors declare no potential conflict of interest concerning this article.

AUTHOR CONTRIBUTIONS: Each author made significant, individual contributions to the development of this manuscript. DPLA and BA were equally responsible for the research and the preparation of this paper.

\section{REFERENCES}

1. Fabry G. Clinical practice: the spine from birth to adolescence. Eur J Pediatr. 2009;168(12):1415-20.

2. Veldhuizen AG, Wever DJ, Webb PJ. The aetiology of idiopathic scoliosis: biomechanical and neuromuscular factors. Eur Spine J. 2000;9(3):178-84.

3. Negrini S, Aulisa AG, Aulisa L, Circo AB, de Mauroy JC, Durmala J, et al. 2011 SOSORT guidelines: Orthopaedic and Rehabilitation treatment of idiopathic scoliosis during growth. Scoliosis. 2012;7(1):3.

4. Chromy CA, Carey MT, Balgaard KG, laizzo PA. The potential use of axial spinal unloading in the treatment of adolescent idiopathic scoliosis: a case series. Arch Phys Med Rehabil. 2006;87(11):1447-53.

5. Driscoll M, Aubin CE, Moreau A, Villemure I, Parent S. The role of spinal concave-convex biases in the progression of idiopathic scoliosis. Eur Spine J. 2009;18(2):180-7.

6. Tosato JP, Caria PHF. Avaliação da atividade muscular na escoliose. Rev Bras Crescimento Desenvolvimento Hum. 2009;19(1):98-102.

7. Stylianides GA, Beaulieu M, Dalleau G, Rivard CH, Allard P. lliac crest orientation and geometry in able-bodied and non-treated adolescent idiopathic scoliosis girls with moderate and severe spinal deformity. Eur Spine J. 2012;21(4):725-32.

8. Trobisch P, Suess O, Schwab F. Idiopathic scoliosis. Dtsch Arztebl Int. 2010;107(49):875-83.

9. Bradford SD, Lonstein JE, Moe JH, O JW, O JW, Winter RB, et al. Escoliose e outras deformidades da coluna: O livro de Moe. 2a. edição. São Paulo: Livraria Santos Editora; 1994

10. de Sèze M, Cugy E. Pathogenesis of idiopathic scoliosis: a review. Ann Phys Rehabil Med. 2012;55(2):128-38.

11. Netter FH. Atlas de anatomia humana. 5a. edição. Rio de Janeiro: Elsevier; 2011.

12. Neumann DA. Cinesiologia do aparelho musculoesquelético: fundamentos para a reabilitação física. 2a. ed. Rio de Janeiro: Elsevier; 2011.

13. Souchard PE. O papel biomecânico dos músculos espinhais - sua implicação na escoliose. Fisioter Bras. 2001;2(6):369-78.

14. Ovadia D. Classification of adolescent idiopathic scoliosis (AIS). J Child Orthop. 2013;7(1):25-8.

15. Risser JC. The classic: The iliac apophysis: an invaluable sign in the management of scoliosis. 1958. Clin Orthop Relat Res. 2010;468(3):643-53.

16. Júnior PCL, Pellegrino L, Cafaro MFS, Meves R, Landin E, Avanzi O. Escoliose Idiopática do Adolescente (EIA): perfil clinic e radiográfico da lista de espera para tratamento cirúrgico em hospital terciário de alta complexidade do Sistema public de saúde brasileiro. Coluna/Columna. 2011;10(2):111-5.

17. Ferreira DMA, Delfino HLA. Avaliação quantitativa da escoliose idiopática: concordância das mensurações da gibosidade e correlações com medidas radiológicas. Rev Bras Fisioter. 2001;5(2):73-86.

18. Wajchenberg M, Puertas EB, Zatz Mayana. Estudo da prevalência da escoliose idiopática do adolescente em pacientes brasileiros. Coluna/Columna. 2005:4(3):113-68.

19. Zabjek KF, Leroux MA, Coillard C, Prince F, Rivard CH. Postural characteristics of adolescents with idiopathic scoliosis. J Pediatr Orthop. 2008;28(2):218-24.

20. Cheung KM, Wang T, Qiu GX, Luk KD. Recent advances in the aetiology of adolescent idiopathic scoliosis. Int Orthop. 2008;32(6):729-34.

21. Burwell RG, Dangerfield PH, Moulton A, Grivas TB, Cheng JC. Whither the etiopathogenesis (and scoliogeny) of adolescent idiopathic scoliosis? Incorporating presentations on scoliogeny at the 2012 IRSSD and SRS meetings. Scoliosis. 2013;8(1):4.

22. Diab AA. The role of forward head correction in management of adolescent idiopathic scoliotic patients: a randomized controlled trial. Clin Rehabil. 2012;26(12):1123-32.

23. Weiss HR, Goodall D. The treatment of adolescent idiopathic scoliosis (AIS) according to present evidence. A systematic review. Eur J Phys Rehabil Med. 2008;44(2):177-93.

24. do Espírito Santo A, Guimarães LV, Galera MF. Prevalence of idiopathic scoliosis and associated variables in schoolchildren of elementary public schools in Cuiabá, state of Mato Grosso, 2002. Rev Bras Epidemiol. 2011;14(2):347-56.

25. Mordecai SC, Dabke HV. Efficacy of exercise therapy for the treatment of adolescent idiopathic scoliosis: a review of the literature. Eur Spine J. 2012;21(3):382-9.

26. Howick J, Chalmers I, Glasziou P, Greenhalgh T, Heneghan C, Liberati A, et al. Explanation of the 2011 Oxford Centre for Evidence-Based Medicine (OCEBM) Levels of Evidence (Background Document). Oxford Centre for Evidence-Based Medicine. Acesso em 14/12/2015. Disponível em: http://www.cebm.net/index.aspx?o=5653

27. Pingot M, Czernicki J, Kubacki J. Assessment of muscle strength of hip joints in children with idiopathic scoliosis. Ortop Traumatol Rehabil. 2007;9(6):636-43.

28. Cheung J, Veldhuizen AG, Halberts JP, Sluiter WJ, Van Horn JR. Geometric and electromyographic assessments in the evaluation of curve progression in idiopathic scoliosis. Spine (Phila Pa 1976). 2006;31(3):322-9.

29. Lin JJ, Chen WH, Chen PQ, Tsauo JY. Alteration in shoulder kinematics and associated muscle activity in people with idiopathic scoliosis. Spine (Phila Pa 1976). 2010;35(11):1151-7.

30. Cheung J, Halbertsma JP, Veldhuizen AG, Sluiter WJ, Maurits NM, Cool JC, et al. A preliminary study on electromyographic analysis of the paraspinal musculature in idiopathic scoliosis. Eur Spine J. 2005;14(2):130-7.

31. Gaudreault N, Arsenault AB, Larivière C, DeSerres SJ, Rivard CH. Assessment of the paraspinal muscles of subjects presenting an idiopathic scoliosis: an EMG pilot study. BMC Musculoskelet Disord. 2005;6:14.

32. Schmid AB, Dyer L, Böni T, Held U, Brunner F. Paraspinal muscle activity during symmetrical and asymmetrical weight training in idiopathic scoliosis. J Sport Rehabil. 2010;19(3):315-27.

33. Mahaudens P,Thonnard JL, Detrembleur C. Influence of structural pelvic disorders during standing and walking in adolescents with idiopathic scoliosis. Spine J. 2005;5(4):427-33.

34. de Oliveira AS, Gianini PE, Camarini PM, Bevilaqua-Grossi D. Electromyographic analysis of paravertebral muscles in patients with idiopathic scoliosis. Spine (Phila Pa 1976). 2011;36(5):E334-9

35. Tsai YT, Leong CP, Huang YC, Kuo SH, Wang HC, Yeh HC, et al. The electromyographic responses of paraspinal muscles during isokinetic exercise in adolescents with idiopathic scoliosis with a Cobb's angle less than fifty degrees. Chang Gung Med J. 2010:33(5):540-50.

36. Bassani E, Candotti CT, Pasini M, Melo M, La Torre M. Avaliação da ativação neuromuscular em indivíduos com escoliose através da eletromiografia de superfície. Rev Bras Fisioter. 2008;12(1):13-9.

37. Chwała W, Koziana A, KasperczykT, Walaszek R, Płaszewski M. Electromyographic assessment of functional symmetry of paraspinal muscles during static exercises in adolescents with idiopathic scoliosis. Biomed Res Int. 2014;2014:573276.

38. Sahgal V, Shah A, Flanagan N, Schaffer M, Kane W, Subramani V, et al. Morphologic and morphometric studies of muscle in idiopathic scoliosis. Acta Orthop Scand. 1983;54(2):242-51 